\title{
Phytoextraction, Accumulation and Toxicological Effects of 1-Tetradecyl-3-Methylimidazolium Ionic Liquid in Ryegrass
}

Mihebai Yilimulati

Xinjiang Normal University

Hong Du

Xinjiang Normal University

Wei Wu

Xinjiang Normal University

Nuzahat Habibul ( $\square$ nuzahat@mail.ustc.edu.cn )

Xinjiang Normal University

Research Article

Keywords: Ionic liquids, [C14mim]Br, Ryegrass, Phytoextraction

Posted Date: June 28th, 2021

DOl: https://doi.org/10.21203/rs.3.rs-594739/v1

License: (c) (i) This work is licensed under a Creative Commons Attribution 4.0 International License. Read Full License 


\section{Abstract}

Ionic liquids are widely used in many fields due to their extremely tunable nature and exceptional properties. The extensive application of ionic liquids raises great concerns regarding their bioaccumulation potential and adverse effects on organisms.Green plants have a great potential for uptake of persistent xenobiotics from aquatic and terrestrial environment. However, the assimilation and bioaccumulation of 1-tetradecyl-3-methylimidazolium bromide $\left(\left[\mathrm{C}_{14} \mathrm{mim}\right] \mathrm{Br}\right)$ has not been studied in plantsyet. In order to explore the phytoaccumulation of $\left[\mathrm{C}_{14} \mathrm{mim}\right]^{+}$, ryegrass were exposed to $\left[\mathrm{C}_{14} \mathrm{mim}\right] \mathrm{Br}$ with hydroponic experiment. The effects of $\left[\mathrm{C}_{14}\right.$ mim]Brdosages on growth index, chlorophyll content, malondialdehyde (MAD) content and antioxidant enzyme activity of ryegrass were investigated. The toxic effects of $\left[\mathrm{C}_{14}\right.$ mim]Bron ryegrass growth increased with increasing initial concentration. The high initial concentration treatment resulted in rapid changes in physiological characteristics in ryegrass tissue. $\left[\mathrm{C}_{14} \mathrm{mim}\right]^{+}$ions were mainly accumulated in root tissue and partly translocated to the above ground part of ryegrass.[ $\left[\mathrm{C}_{14} \mathrm{mim}\right]^{+}$was observed in the highest concentration $(314.35 \mu \mathrm{g} / \mathrm{gin}$ root and $101.42 \mu \mathrm{g} / \mathrm{gin}$ aboveground partsof ryegrass) with $10 \mathrm{mg} / \mathrm{L}$ of $\left[\mathrm{C}_{14} \mathrm{mim}\right] \mathrm{Br}$.Our results demonstrated that ryegrass can uptake and accumulate $\left[\mathrm{C}_{14} \mathrm{mim}\right]^{+}$and is therefore a suitable species for phytroremediationof trace amount of $\left[\mathrm{C}_{14} \mathrm{mim}\right]^{+}$and possibly other ionic liquids.

\section{Introduction}

Ionic liquids (ILs), a class of "green solvent", are widely used in numerous industrial and pharmaceutical applications. In recent years, ILs have aroused increasing concern as emerging aquatic pollutants due to their unique chemical-physical properties with water solubility and low biodegradability (Liu et al. 2015b, Oskarsson \&Wright 2019). Among the ILs, imidazolium-based compounds have caused much attention due to their toxicity to organisms at significantly lower concentration than those of conventional solvents. Numerous studies have confirmed that imidazolium-based ILs have the potential to cause adverse effects in aquatic and terrestrial organisms. For instance, imidazolium-based ILs were reported to caused growth inhibition, chlorophyll content decrease and oxidative damage in aquatic and terrestrial plants (Xu et al. 2020). Moreover, they can even accumulate in plant tissue and affect physiological processes in plants (Habibul et al. 2019, Habibul et al. 2021, Hu et al. 2020). These reports also indicate that ILs may present a potential to transferred to the edible portion of crops (Habibul et al. 2020). Root uptake and accumulation of ILs could represent an entry point of ILs into the food chain, thus potentially causing health risk.

Ionic liquids are highly water soluble, thus they presumably pose more environmental risks due to the high permeability of hydrophilic chemical into aquatic ecosystem (Egorova et al. 2017). So far, studies about the imidazolium-based ILs mainly focused on the toxic effects of different concentrations or different side chain lengths of ILs. Very few studies reported the degradation of ILs by chemical process, such as advanced oxidation process and electrochemical oxidation process (Fabiańska et al. 2012, Spasiano et al. 2016, Thuy Pham et al. 2010). As a green remediation technology, the cost-effective 
operation and ecological perspective of phytoremediation technology make it an attractive alternative for removal of organic pollutants such as ionic liquid (Limmer \&Burken 2016). Due to their excellent water solubility and high bioavailability, imidazolium-based ILs might easily penetrate into organisms such as plant root system (Polesel et al. 2015). Recently, we reported that ryegrass can uptake and accumulate 1butyl-3-methylimidazolium $\left(\left[\mathrm{C}_{4} \mathrm{mim}\right]^{+}\right)$, and its toxicity increased with increasing treatment concentration (Habibul et al. 2019). Plant uptake of organic chemicals depends on their physicochemical properties such as molecular weight, chemical structure and hydrophobicity (Sicbaldi et al. 1997). Previous studies have demonstrated that the hydrophobicity and toxicity of imidazolium-based ILs were highly related to the side alkyl chain length (Grzonkowska et al. 2016). 1-tetradecyl-3-methylimidazolium bromide $\left(\left[\mathrm{C}_{14} \mathrm{mim}\right] \mathrm{Br}\right)$ is a long alky chain ILs, with higher toxicity than other imidazolium-based ILs such as $\left[\mathrm{C}_{\mathrm{x}} \mathrm{mim}\right]^{+}(\mathrm{x}<8)$. While there is no study assessing the uptake and accumulation potential of $\left[\mathrm{C}_{14} \mathrm{mim}\right]^{+}$in plant.

In this study, we aim to investigate the uptake and accumulation of $\left[\mathrm{C}_{14} \mathrm{mim}\right]^{+}$by ryegrass and the toxic effects of $\left[\mathrm{C}_{14} \mathrm{mim}\right]^{+}$on ryegrass physiochemical characters. The intent of this study was to elucidate $\left[\mathrm{C}_{14} \mathrm{mim}\right]^{+}$phytoremediation potential in response to different concentration of $\left[\mathrm{C}_{14} \mathrm{mim}\right]^{+}$in aquatic environment. The results may provide a new insight into plant uptake and accumulation of $\left[\mathrm{C}_{14} \mathrm{mim}\right]^{+}$ from contaminated water, and act as a further verification of using ryegrass for phytoremediation of imidazolium-based ILs from aquatic ecosystem.

\section{Materials And Methods}

\subsection{Plant culture and exposure experiments}

The ryegrass seeds were sterilized with $1 \% \mathrm{NaClO}$ for 15 minutes, immersed in distilled water for $12 \mathrm{~h}$, and then germinated on sterile moist filter paper in a growth chamber at $25^{\circ} \mathrm{C}$. When the ryegrass seedling were about $8 \mathrm{~cm}$ height, they were transferred to $250 \mathrm{~mL}$ foil-wrapped triangular flasks, and then cultivated for 2 weeks with 1/2 Hoagland nutrient solution. Ryegrass seedlings of uniform size were selected and cultivated in nutrient solutions with different initial concentrations of $\left[\mathrm{C}_{14} \operatorname{mim}\right] \operatorname{Br}(0,1,2,5$, $10 \mathrm{mg} / \mathrm{L}$ ). Three replicates for each concentration and blank control were conducted. Evaporation and transpiration of whole plants were determined by the water level labeled on the flask, and deionized water was injected into the flask every two days to supplement the transpiration losses. Water samples ( 0.5 $\mathrm{mL}$ ) were sampled by syringe at intervals of $3,6,9,12$ and 15 days. All the water samples were filtered through $0.2 \mu \mathrm{m}$ nylon filter and stored at $4{ }^{\circ} \mathrm{C}$ until analysis. After 15 days exposure experiment, the plants were harvested, divided into roots and leaves, weighed and stored at $-20^{\circ} \mathrm{C}$ in the seal sample bag until extraction.

\subsection{Growth inhibition test}


The root length, leaf length and fresh weight of each ryegrass were measured at the beginning and at the end of the experiment. The relative inhibition of growth rates in each concentration were calculated by Eq. (1) and the percent growth rate inhibition ratio I\% was calculated using Eq. (2) (Chen et al. 2018):

$$
\begin{aligned}
\mu_{t} & =\frac{\ln B_{i}-\ln B_{0}}{t_{i}-t_{0}} \\
\mathrm{I} \% & =\frac{\mu_{0}-\mu_{t}}{\mu_{0}} \times 100 \%
\end{aligned}
$$

where $\mu_{\mathrm{t}}$ is the average specific growth rate from the beginning $t_{0}$ to the end $t_{i}$, and $B_{0}$ and $B_{j}$ are the weights of the biomass at time $t_{0}$ to $t_{i}$, respectively. $\mu_{0}$ is the mean value of $\mu$ for the untreated plant control.

\subsection{Determination of physiological indicators}

Chlorophyll content was determined according to Xu et al. (Xu et al. 2018). Briefly, $0.2 \mathrm{~g}$ of fresh ryegrass leaves were placed in $25 \mathrm{~mL}$ tubes and immersed in $25 \mathrm{~mL}$ of $80 \%$ acetone for $12 \mathrm{~h}$ in the dark. The absorbance values of extracts was measured by the UV-Vis light spectrophotometer at 663 and $646 \mathrm{~nm}$, respectively.

Malondialdehyde (MDA) content was determined following the methods described previously (Biczak 2016). $1 \mathrm{~mL}$ of ryegrass tissue solution was mixed with $2 \mathrm{~mL} 0.1 \%$ thiobarbituric acid. The mixture was reacted in a boiling water bath at $100^{\circ} \mathrm{C}$ for $15 \mathrm{~min}$, and the reaction was stopped by rapid addition to ice water. Absorbance values were measured at $450 \mathrm{~nm}, 532 \mathrm{~nm}$, and $600 \mathrm{~nm}$, respectively.

$0.5 \mathrm{~g}$ of ryegrass roots and leaves were weighed separately and grounded with liquid $\mathrm{N}_{2}$ in a mortar and homogenized in $8 \mathrm{~mL}$ of $50 \mathrm{mM}$ phosphate buffer $(\mathrm{pH} 7.0)$. The homogenates were centrifuge at 10,000 $\mathrm{rpm}$ for $10 \mathrm{~min}$ at $4^{\circ} \mathrm{C}$. The supernatant was collected as a crude enzyme solution of ryegrass tissue at $4^{\circ} \mathrm{C}$ for further assays for ismutase (SOD), catalase (CAT) and peroxidase (POD)activities (Chandra Rai et al. 2012). SOD activities were determined by measuring the inhibition in photochemical reduction of nitroblue tetrazolium (NBT) at $560 \mathrm{~nm}$. POD activities were assayed at $470 \mathrm{~nm}$ by determining the oxidation of guaiacol by $\mathrm{H}_{2} \mathrm{O}_{2}$. CAT activities were determined as the decrease in absorbance value at $240 \mathrm{~nm}$ over time due to the consumption of $\mathrm{H}_{2} \mathrm{O}_{2}$.

\subsection{Extraction and analysis}

Fresh roots and leaves of ryegrass samples $(0.5 \mathrm{~g})$ were extracted using extraction solvent $(0.5 \%$ formic acid: methanol $=1: 1$ ). Briefly, plant tissues were homogenized under liquid nitrogen conditions, and $8 \mathrm{~mL}$ of extraction solvent was added, followed by shaking at $250 \mathrm{rpm}$ for 24 hours, and centrifugation at 9000 rpm for $30 \mathrm{~min}$. The collected extracts were dried by $\mathrm{N}_{2}$ and redissolved in $1 \mathrm{~mL}$ methanol and filtered through $0.22 \mu \mathrm{m}$ PTFE filter. The extracts were analyzed on a high performance liquid chromatography (Agilent 1290) coupled with an Agilent 6460 mass spectrometer. An Agilent $C_{18}$ column $(150 \mathrm{~mm} \times 4.6$ $\mathrm{mm}$, particle size of $5 \mu \mathrm{m})$ was used for separation. The mobile phase consisted of phase $A(0.5 \%$ formic 
acid) and phase $B$ (acetonitrile) mixture ( $35: 65$ by volume) for $\left[\mathrm{C}_{14} \mathrm{~min}\right] \mathrm{Br}$, the flow rate was $0.30 \mathrm{~mL} / \mathrm{min}$, and the sample injection volume was $10 \mu \mathrm{L}$. [ $\left.\mathrm{C}_{14} \mathrm{~min}\right] \mathrm{Br}$ concentration measured in fresh shoot and root samples were converted to their concentrations based on the fresh weight of ryegrass shoots and roots. To elucidate the accumulation and transloctation pathways of $\left[\mathrm{C}_{14} \mathrm{~min}\right] \mathrm{Br}$ in ryegrass, the translocation factors were calculated by:

$\mathrm{TF}=\mathrm{C}_{\text {shoot }} / \mathrm{C}_{\text {root }}(3)$

where $\mathrm{C}_{\text {root }} \mathrm{C}_{\text {shoot }}$ are the $\left[\mathrm{C}_{14} \mathrm{~min}\right] \mathrm{Br}$ concentrations in the ryegrass root and shoot, respectively.

\subsection{Statistical analysis}

All of the above experimental data were analyzed by SPSS 20.0 statistical software and analysis of variance (ANOVA). Treatment means were compared with the least significant difference (LSD) test at a significance level of $P<0.05$.

\section{Results}

\section{1 $\left[\mathrm{C}_{14} \mathrm{mim}\right] \mathrm{Br}$ removal by ryegrass}

The relative $\left[\mathrm{C}_{14} \mathrm{mim}\right]^{+}$concentration $\left(\mathrm{C} / \mathrm{C}_{0}\right)$ in growth medium was calculated by dividing the concentration of $\left[\mathrm{C}_{14} \mathrm{mim}\right]^{+}$at a certain time with the initial concentration. As shown in Fig. $1,\left[\mathrm{C}_{14} \mathrm{mim}\right] \mathrm{Br}$ content in the substrate medium decreased with time. Specifically, C/ $C_{0}$ with $1 \mathrm{mg} / \mathrm{L}$ and $2 \mathrm{mg} / \mathrm{L}$ of $\left[\mathrm{C}_{14} \mathrm{mim}\right] \mathrm{Br}$ in the growth medium decreased rapidly within 15 days and reached the lowest level at 0.32 $\mathrm{mg} / \mathrm{L}$ and $0.53 \mathrm{mg} / \mathrm{L}$, respectively. A high removal efficiency of $68 \%$ was achieved within 15 days with 1 $\mathrm{mg} / \mathrm{L}\left[\mathrm{C}_{14} \mathrm{mim}\right] \mathrm{Br}$. The average removal rates of ryegrass to $1,2,5$, and $10 \mathrm{mg} / \mathrm{L}$ of $\left[\mathrm{C}_{14} \mathrm{mim}\right] \mathrm{Br}$ were $0.045,0.031,0.018$, and $0.016 \mathrm{mg} / \mathrm{L} / \mathrm{d}$, respectively. At the end of experiment, the removal efficiencies of $\left[\mathrm{C}_{14} \mathrm{mim}\right] \mathrm{Br}$ were $68 \%, 47 \%, 28 \%$, and $24 \%$ with $1,2,5$, and $10 \mathrm{mg} / \mathrm{L}$ of $\left[\mathrm{C}_{14} \mathrm{mim}\right] \mathrm{Br}$.

\subsection{Accumulation and transportation of $\left[\mathrm{C}_{14} \mathrm{mim}\right] \mathrm{Br}$ in ryegrass.}

After 15 days of treatment with $\left[\mathrm{C}_{14} \mathrm{mim}\right] \mathrm{Br}$, the contents of $\left[\mathrm{C}_{14} \mathrm{mim}\right] \mathrm{Br}$ in different ryegrass tissues were extracted and detected. The results showed that ryegrass could uptake $\left[\mathrm{C}_{14} \mathrm{mim}\right] \mathrm{Br}$ through the roots and transport to the aboveground parts (Fig. 2). After treatment with $1 \mathrm{mg} / \mathrm{L}, 2 \mathrm{mg} / \mathrm{L}, 5 \mathrm{mg} / \mathrm{L}, 10 \mathrm{mg} / \mathrm{L}$ of $\left[\mathrm{C}_{14} \mathrm{mim}\right] \mathrm{Br}$, the concentrations of $\left[\mathrm{C}_{14} \mathrm{mim}\right] \mathrm{Br}$ in the ryegrass roots were $180,222,256,312 \mu \mathrm{g} / \mathrm{g} \cdot \mathrm{FW}$, respectively, while in the ryegrass leaves the concentrations were $81,90,96,105 \mu \mathrm{g} / \mathrm{g} \cdot \mathrm{FW}$, respectively. Obviously, $\left[\mathrm{C}_{14} \mathrm{mim}\right] \mathrm{Br}$ accumulation in the roots was much higher than that in the leaves. The total $\left[\mathrm{C}_{14} \mathrm{mim}\right] \mathrm{Br}$ accumulation in ryegrass was affected by the initial concentration of $\left[\mathrm{C}_{14} \mathrm{mim}\right] \mathrm{Br}$ in the hydroponic culture medium, and the accumulation amount was positively correlated with the concentration $(R=0.93, P<0.05)$. Translocation factor is an important indicator for measuring the above 
ground accumulation and transport capacity of $\left[\mathrm{C}_{14} \mathrm{mim}\right] \mathrm{Br}$ by ryegrass(Trapp 2000). The ryegrass transfer factor under all treatment concentrations were less than 1 (Table 1), indicating that ryegrass was not a hyperaccumulator plant under the treatment(Bedabati Chanu \&Gupta 2016). However, in consideration of $\left[\mathrm{C}_{14} \mathrm{mim}\right] \mathrm{Br}$ with lower concentration had the tendency to be taken up by the ryegrass roots, ryegrass still have great potential for phytoremediation of trace amount of $\left[\mathrm{C}_{14} \mathrm{mim}\right] \mathrm{Br}$.

Table 1

Effects of $\left[\mathrm{C}_{14}\right.$ mim] Br with different concentration on the growth of ryegrass

\begin{tabular}{|llll|}
\hline Concentration(mg/L) & Fresh weight $(\mathrm{g})$ & Root length $(\mathrm{cm})$ & Leaf length $(\mathrm{cm})$ \\
\hline 0 & $4.66 \pm 0.26$ & $7.31 \pm 0.61$ & $15.33 \pm 0.62$ \\
\hline 1 & $2.74 \pm 0.13$ & $4.33 \pm 0.23$ & $12.61 \pm 0.14$ \\
\hline 5 & $1.91 \pm 0.06$ & $2.56 \pm 0.40$ & $8.06 \pm 0.49$ \\
\hline 10 & $0.92 \pm 0.04$ & $1.43 \pm 0.09$ & $5.76 \pm 0.61$ \\
\hline
\end{tabular}

Table 2

The removal efficiency and transfer factor of ryegrass at different concentrations $\left[\mathrm{C}_{14} \mathrm{mim}\right] \mathrm{Br}$

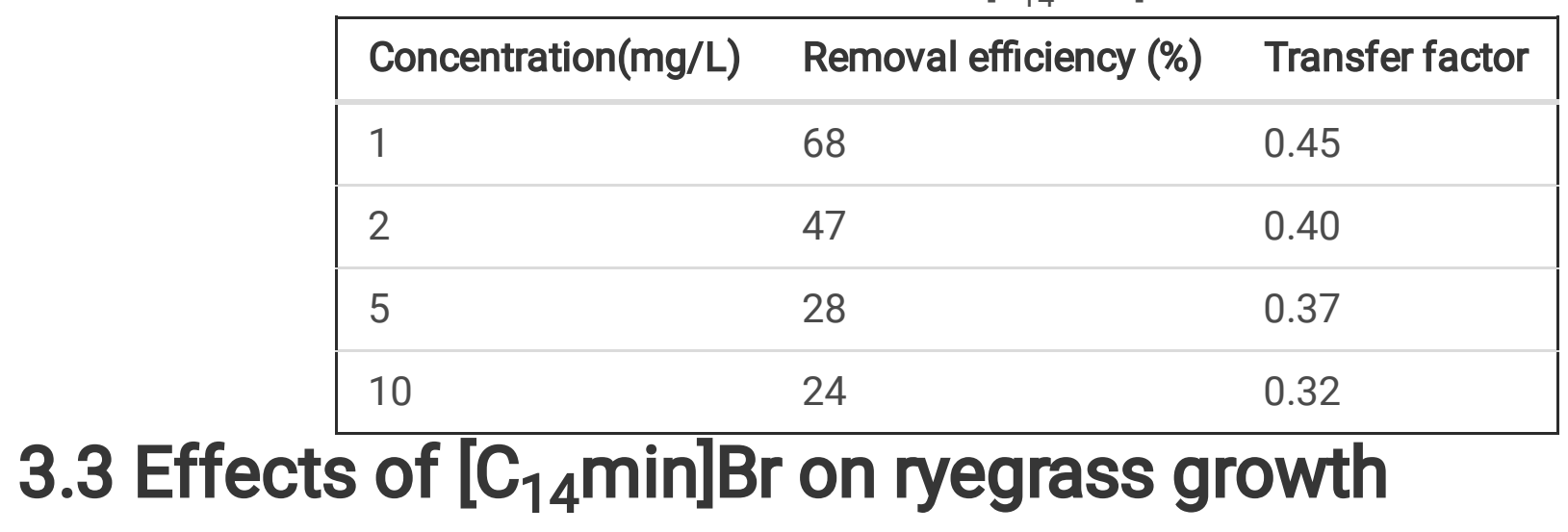

It was reported that ionic liquids lead to physiological and molecular changes in plants that adversely affect their fresh biomass growth and development of root/leaf elongation (Habibul et al. 2021). The fresh biomass, root and shoot lengths of ryegrass with different $\left[\mathrm{C}_{14} \mathrm{mim}\right] \mathrm{Br}$ concentration treatment are shown in Table 1. The exposure of $>2 \mathrm{mg} / \mathrm{L}$ of $\left[\mathrm{C}_{14} \mathrm{mim}\right] \mathrm{Br}$ significantly reduced the ryegrass fresh biomass and inhibited root/shoot growth compared with the control plants $(P<0.05)$. Ryegrass plants also showed stunt, leaf chlorosis and root necrosis under $5 \mathrm{mg} / \mathrm{L}$ and $10 \mathrm{mg} / \mathrm{L} \mathrm{of}\left[\mathrm{C}_{14} \mathrm{mim}\right] \mathrm{Br}$ exposure (Fig. $3 \mathrm{a}$ and $3 \mathrm{~b}$ ). When the $\left[\mathrm{C}_{14} \mathrm{mim}\right] \mathrm{Br}$ concentration increased from 0 to $10 \mathrm{mg} / \mathrm{L}$, the ryegrass growth rate decreased from $0.04 \mathrm{~cm} / \mathrm{d}$ to $0.01 \mathrm{~cm} / \mathrm{d}$. The exposure to $10 \mathrm{mg} / \mathrm{L}\left[\mathrm{C}_{14} \mathrm{mim}\right] \mathrm{Br}$ resulted in decreases in roots and leaves growth by $88.9 \%$ and $82.6 \%$, respectively. The ryegrass biomass growth inhibition rate with different treatment $\left[\mathrm{C}_{14} \mathrm{mim}\right] \mathrm{Br}$ concentration were $27.8 \%, 45.2 \%, 69.9 \%, 83.7 \%$, respectively. The 
inhibitory effect of [ $\left.\mathrm{C}_{14} \mathrm{mim}\right] \mathrm{Br}$ on ryegrass was expressed by the half-maximum effect concentration $\mathrm{EC}_{50}$, which was calculated to be $3.3 \mathrm{mg} / \mathrm{L}$.

\subsection{Effect of $\left[\mathrm{C}_{14} \mathrm{~min}\right] \mathrm{Br}$ on chlorophyll and MDA content in ryegrass}

Chlorophyll is the most important pigment for photosynthesis in plants, which has been considered a sensitive indicator of abiotic stress. Variation of chlorophyll content in ryegrass leaves depended on the [ $\left.\mathrm{C}_{14} \mathrm{~min}\right] \mathrm{Br}$ concentration in the growth medium (Fig. 4A). There was no significant difference in chlorophyll a and chlorophyll b contents in lower $\left[\mathrm{C}_{14} \mathrm{~min}\right] \mathrm{Br}$ concentration treatment $(\mathrm{P}>0.05)$. However, compared to the control, the chlorophyll a and chlorophyll b contents in ryegrass leaves showed downtrends when exposed to $5 \mathrm{mg} / \mathrm{L}$ and $10 \mathrm{mg} / \mathrm{L}\left[\mathrm{C}_{14} \mathrm{~min}\right] \mathrm{Br}$, which was decreased by $54 \%$ and $72 \%$ (chlorophyll a), and 51\% and 67\% (chlorophyll b), respectively $(P<0.05)$.

MDA is the final product of membranous peroxidation, and MDA level can indicate the degree of cell membrane damage. Figure 4 reveals that MDA contents in roots and leaves were significantly affected by the concentration of $\left[\mathrm{C}_{14}\right.$ min $] \mathrm{Br}$ in the growth medium $(\mathrm{R}=0.92, \mathrm{R}=0.97, \mathrm{P}<0.05)$. It can be clearly observed from Fig. $4 \mathrm{~B}$ that the MDA content in the roots was significantly higher than that in the leaves. The leaf MDA contents ranged from $25.67 \pm 2.71 \mathrm{nmol} / \mathrm{g}$ to $71.91 \pm 2.43 \mathrm{nmol} / \mathrm{g}$, while the root MDA contents ranged from $60.09 \pm 1.95 \mathrm{nmol} / \mathrm{g}$ to $129.86 \pm 3.72 \mathrm{nmol} / \mathrm{g}$. Compared with the control, $\left[\mathrm{C}_{14} \mathrm{~min}\right] \mathrm{Br}$ exposure at $1-10 \mathrm{mg} / \mathrm{L}$ significantly increased root MDA contents by $20.12 \%-115.11 \%$.

\subsection{Effect of [ $\left.\mathrm{C}_{14} \mathrm{~min}\right] \mathrm{Br}$ on antioxidant enzyme system in ryegrass.}

SOD, CAT, and POD are three major enzymes in the organism's antioxidant defense system. SOD is a natural eliminator of superoxide radicals that neutralizes the $\mathrm{O}^{2-}$ into $\mathrm{H}_{2} \mathrm{O}_{2}$ (Yuan et al. 2018). However, this reaction produces $\mathrm{H}_{2} \mathrm{O}_{2}$, which can be decomposed into harmless oxygen and water under the synergistic action of CAT and POD. Previous studies suggested that imidazolium based ILs induced oxidative stress in plants by generating reactive oxygen species (ROS) (Zhang et al. 2011). Therefore, the antioxidant defense mechanisms in ryegrass were measured by analyzing SOD, CAT and POD activities. The antioxidant enzyme activity increased with increasing $\left[\mathrm{C}_{14} \mathrm{~min}\right] \mathrm{Br}$ concentration in growth medium, and the increasing trends were significantly different between root and leaves, and between antioxidant enzymes. When exposed to $10 \mathrm{mg} / \mathrm{L}$ of $\left[\mathrm{C}_{14} \mathrm{~min}\right] \mathrm{Br}$, SOD, CAT and POD activities increased in roots by $137.7 \%, 80.2 \%$ and $71.7 \%$ compared with those in the control, respectively $(P<0.05)$. Similarly, SOD, CAT and POD activities in leaves increased by $96.7 \%, 134.1 \%$ and $30.8 \%$, respectively. However, the low $\left[\mathrm{C}_{14} \mathrm{~min}\right] \mathrm{Br}$ concentration $(1 \mathrm{mg} / \mathrm{L})$ treatment did not significantly affect the antioxidant enzyme activities in ryegrass.

\section{Discussion}


Previous studies have demonstrated the uptake of imidazolium ILs into plants and subsequently accumulated in different parts of plant tissues (Habibul et al. 2019, Hu et al. 2020). However, the uptake and translocation behavior of different imidazolium based ILs in a plant is highly varied and complex. In this study, the removal efficiency of $\left[\mathrm{C}_{14} \mathrm{mim}\right] \mathrm{Br}$ by ryegrass ranged from $28-64 \%$, which was notably lower than that of shorter alkyl chain length of ILs (71\%-100\% for $\left.\left[\mathrm{C}_{4} \mathrm{mim}\right] \mathrm{Br}\right)$ (Habibul et al. 2019). As described in our previous study, the removal efficiency of different alkyl chain length of imidazolium based ILs by ryegrass decreased with increase of side alkyl chain length of IL (Habibul et al. 2021). We speculate that the possible explanation for the less-efficient root uptake or removal of $\left[\mathrm{C}_{14} \mathrm{mim}\right] \mathrm{Br}$ by ryegrass might be due to the significant toxic effects of long alkyl chain length of ILs for ryegrass roots. Generally, water and chemicals can enter the root via the root hairs and root tips, which is ascribed to the bulk of root surface area for plant nutrient and other small solutes adsorption(Miller et al. 2016). However, the toxic effects of $\left[\mathrm{C}_{14} \mathrm{mim}\right] \mathrm{Br}$ significantly inhibited ryegrass growth, extremely decreased fibrous root system of ryegrass, which decreased the root absorption surface for $\left[\mathrm{C}_{14} \mathrm{mim}\right] \mathrm{Br}$ in the growth medium and consequently impeded $\left[\mathrm{C}_{14} \mathrm{mim}\right] \mathrm{Br}$ translocation into root tissue. When cationic xenobiotics enter the plant roots, they would tend to retention in root cells due to the electrostatic attraction to negatively charged cell walls and membrane within the apoplast (Nason et al. 2019, Sicbaldi et al. 1997). In the present study, [ $\left.\mathrm{C}_{14} \mathrm{mim}\right] \mathrm{Br}$ showed the highest propensity to accumulate in ryegrass roots, and few of $\left[\mathrm{C}_{14} \mathrm{mim}\right] \mathrm{Br}$ transported to the above ground parts of ryegrass. The higher root accumulation of $\left[\mathrm{C}_{14} \mathrm{mim}\right] \mathrm{Br}$ may also indicate difficulty bypass the Casparian strip to reach the xylem and phloem and sequestered in root cell vacuoles before they enter the vasculature (Miller et al. 2016). The higher ILs accumulation in the plant roots than that in leaves was consistent with previous researches (Habibul et al. 2021, Hu et al. 2020). Transfer factor can be a useful parameter to predict translocation ability of compounds in-plant tissue across species. In this study, TF values below 1 indicate that $\left[\mathrm{C}_{14} \mathrm{mim}\right] \mathrm{Br}$ may not be readily transported from roots to shoots in ryegrass. To our best knowledge, the mechanism of xenobiotic cations transportation in plants have not been clearly identified, but it was speculated that ion trapping in the phloem and electrostatic interaction with cells wall may affect the translocation of ionic organic chemicals in the phloem (Trapp 2000,2004). However, since the translocation mechanisms vary by plant species and chemical properties of xenobiotic, there is no plausible explanation on the uptake and translocation mechanism of imidazolium based ILs by ryegrass yet.

Imidazolium based ILs have been reported to be toxic to green plants and the toxicity increased with increasing side alkyl chain length (Habibul et al. 2020, Xu et al. 2020, Xu et al. 2018). Our results indicate that $\left[\mathrm{C}_{14} \mathrm{mim}\right] \mathrm{Br}$ had significant toxic effects on the growth and physiological metabolism of ryegrass. The toxic effect levels are also consistent with $\left[\mathrm{C}_{14} \mathrm{mim}\right] \mathrm{Br}$ accumulation amount in ryegrass tissue. The growth of ryegrass roots, leaves and the increase of fresh weight are significantly inhibited with the increase of $\left[\mathrm{C}_{14} \mathrm{mim}\right] \mathrm{Br}$ concentration and the median effective concentration $\left(\mathrm{EC}_{50}\right)$ value on ryegrass was $3.3 \mathrm{mg} / \mathrm{L}$, which was significantly lower than that of $\left[\mathrm{C}_{4}\right.$ mim $] \mathrm{Br}$ on ryegrass $\mathrm{EC}_{50}(8.29 \mathrm{mg} / \mathrm{L}$ for $\left.\left[\mathrm{C}_{4} \mathrm{mim}\right] \mathrm{Br}\right)$. 
Nowadays, it is clearly established that (i) imidazolium based ILs disturb lipid bilayers of the cell membrane due to stronger ILs-lipid bilayer interactions, and affected plant photosynthesis (Xu et al. 2020); (ii) ROS are generated in the presence of ILs, correlated with physiological plant root/shoot inhibition, oxidative stress, and apoptosis in normal cells (Chen et al. 2018, Xu et al. 2018). In this work, $\left[\mathrm{C}_{14} \mathrm{mim}\right] \mathrm{Br}$ induced a decrease in chlorophyll content in ryegrass leaves, and the inhibition of chlorophyll contents increased with increasing $\left[\mathrm{C}_{14} \mathrm{mim}\right] \mathrm{Br}$ treatment concentration. The decrease in chlorophyll content is an indicator of early debilitation of the plant (Biczak 2016). Studies have shown that ILs can damage the plant thylakoid membrane, which is the basic structure for plants to transfer and convert photosynthetic pigments (Liu et al. 2015a). The inhibition of photosynthesize ability of plants consequently resulted in plant leaf chlorosis and inhibition of plant growth, which is consistent with the dryness of ryegrass leaves in the current experiment.

It is known that plants normally produce ROS in chloroplasts and mitochondria during the respiration and photosynthesis (Karuppanapandian et al. 2011). Abiotic stress has been shown to induce excessive ROS accumulation in plant cell, which results in damaged cell membranes and therefore the inhibition of plant growth. To avoid the adverse effects of ROS, plants activated antioxidant systems, such as altering lipid peroxidation, increasing super dismutase, catalase, peroxidase, and others. In this study, the treatments with different levels of $\left[\mathrm{C}_{14} \mathrm{mim}\right] \mathrm{Br}$ remarkably increased ryegrass root and leaf MDA contents. MDA is a decomposition product of hydroperoxides of membrane and a reliable indicator of abiotic oxidative stress in plants. The imidazolium ring and longer alkyl chain demonstrated the penetration into the lipid bilayer more easily and more deeply due to the strong interaction with lipid head and tail groups, and caused morphological defect of cell membrane and likely led to subsequent production of lipid hydroperoxides (Egorova et al. 2017, Ranke et al. 2007, Stolte et al. 2007). Furthermore, ILs could induce ROS accumulation in plant cells, and subsequently exacerbate the membrane lipid peroxidation process and cause serious damage to cell membrane structure and function (Liu et al. 2017, Riaz et al. 2017). In accordance with increase of MDA contents, SOD, CAT and POD activities also showed increases in ryegrass roots and leaves. According to results, increasing the concentration of $\left[\mathrm{C}_{14} \mathrm{mim}\right] \mathrm{Br}$ resulted in a systematic increase in SOD, CAT and POD activities, and the increases of SOD and CAT activities were notable higher than that of POD. Since SOD activity as the first line of defense against ROS in plant cells, SOD catalyzed the reduction process from highly reactive and potentially toxic superoxide radicals to $\mathrm{H}_{2} \mathrm{O}_{2}$ (Rico et al. 2013). SOD activity also leads to production of $\mathrm{H}_{2} \mathrm{O}_{2}$, which is also harmful to plant cell, and the plants simultaneously provoked CAT activity to efficiently clear the excess $\mathrm{H}_{2} \mathrm{O}_{2}$ and slightly increase POD activity. The antioxidative enzymes in plant cells were also pointed out in previously studies, which indicate that antioxidant enzymes such as SOD, CAT, POD, ascorbate peroxidase and guaiacol peroxidase play a crucial role to eliminate ROS in plants to protect the cells as a response to oxidative stress (Chen et al. 2018, Liu et al. 2015c, Xu et al. 2018).

\section{Conclusion}


This study demonstrated that ryegrass could effectively assimilate long-chain ILs ([ $\left.\left.\mathrm{C}_{14} \mathrm{mim}\right] \mathrm{Br}\right)$ from aquatic environment, and the removal efficiency was related to the treatment concentration. The toxicity results indicate that the concentration of $\left[\mathrm{C}_{14} \mathrm{mim}\right] \mathrm{Br}$ strongly affected the toxicity, and the toxic mechanisms of $\left[\mathrm{C}_{14} \mathrm{mim}\right] \mathrm{Br}$ in plants involved in inducing oxidative stress, causing damage of antioxidative enzymes, and consequently inhibiting photosynthesis and plant growth. Our results showed that ryegrass may be useful for phytoremediation of trace ILs in surface water or constructed wetland. Combined with shorter chain length imidazolium based ILs accumulation in ryegrass as we reported previously, the information regarding $\left[\mathrm{C}_{14} \mathrm{mim}\right] \mathrm{Br}$ phytoaccumulation behavior in ryegrass will be helpful for future development of mechanistic models representing the environmental fate and risk assessment for imidazolium based IL contamination of concern.

\section{Declarations}

\section{Ethics approval and consent to participate}

Not applicable.

\section{Consent for publication}

Not applicable.

\section{Availability of data and materials}

The datasets used and/or analysed during the current study are available from the corresponding author on reasonable request.

\section{Declaration of interests}

The authors declare that they have no known competing financial interests or personal relationships that could have appeared to influence the work reported in this paper.

\section{Funding}

National Natural Science Foundation of China (51968072)

Xinjiang Natural Science Foundation, China (2017D01B31)

Tianshan Talent Program of Xinjiang, China (2017Q083)

Xinjiang Higher Educational Institutions Scientific ResearchProgram, China (XJEDU2017S026)

\section{Authors' contributions}

Mihribanllmurat $₫$ Data curation, Writing- Original draft preparation $₫$ Formal analysis. Hong Du $\llbracket$ Investigation $₫$ Writing- Reviewing and Editing. Wei Wu囚Software, Validation.Nuzahat Habibul区 
Conceptualization, Methodology $₫$ Writing- Reviewing and Editing $₫$ Supervision

\section{Acknowledgments}

The authors wish to thank National Natural Science Foundation of China (51968072), theXinjiang Natural Science Foundation, China (2017D01B31), the Tianshan Talent Program of Xinjiang, China (2017Q083),Xinjiang Higher Educational Institutions Scientific ResearchProgram, China (XJEDU2017S026)for the partial finance support.

\section{References}

1. Bedabati Chanu L, Gupta A (2016): Phytoremediation of lead using Ipomoea aquatica Forsk. in hydroponic solution. Chemosphere 156, 407-411

2. Biczak R (2016): Quaternary ammonium salts with tetrafluoroborate anion: Phytotoxicity and oxidative stress in terrestrial plants. J. Hazard. Mater. 304, 173-185

3. Chandra Rai A, Singh M, Shah K (2012): Effect of water withdrawal on formation of free radical, proline accumulation and activities of antioxidant enzymes in ZAT12-transformed transgenic tomato plants. Plant. Physiol. Bioch. 61, 108-114

4. Chen Z, Zhou Q, Guan W, Wang J, Li Y, Yu N, Wei J (2018): Effects of imidazolium-based ionic liquids with different anions on wheat seedlings. Chemosphere 194, 20-27

5. Egorova KS, Gordeev EG, Ananikov VP (2017): Biological activity of ionic liquids and their application in pharmaceutics and medicine. Chem. Rev. 117, 7132-7189

6. Fabiańska A, Ossowski T, Bogdanowicz R, Czupryniak J, Gnyba M, Odzga T, Janssens SD, Haenen K, Siedlecka EM (2012): Electrochemical oxidation of ionic liquids at highly boron doped diamond electrodes. Physica Status Solidi (a) 209, 1797-1803

7. Grzonkowska M, Sosnowska A, Barycki M, Rybinska A, Puzyn T (2016): How the structure of ionic liquid affects its toxicity to Vibrio fischeri? Chemosphere 159, 199-207

8. Habibul N, Chen JJ, Hu YY, Hu Y, Yin H, Sheng GP, Yu HQ (2019): Uptake, accumulation and metabolization of 1-butyl-3-methylimidazolium bromide by ryegrass from water: Prospects for phytoremediation. Water Res 156, 82-91

9. Habibul N, Ilmurat M, Habibul Z, Hu Y, Ma X (2020): Uptake and accumulation of imidazolium ionic liquids in rice seedlings: Impacts of alkyl chain length. Chemosphere 242, 125228

10. Habibul N, Hu YY, Hu Y, Sheng GP (2021): Alkyl chain length affecting uptake of imidazolium based ionic liquids by ryegrass (Lolium perenne L.). $\mathrm{J}$ Hazard Mater 401, 123376

11. Hu Y, Habibul N, Hu Y Y, Meng F L, Zhang X, Sheng G-P (2020): Mixture toxicity and uptake of 1-butyl3-methylimidazolium bromide and cadmium co-contaminants in water by perennial ryegrass (Lolium perenne L.). J. Hazard. Mater. 386, 121972

12. Karuppanapandian T, Moon JC, Kim C, Manoharan K, Kim W (2011): Reactive oxygen species in plants: their generation, signal transduction, and scavenging mechanisms. Aust. J. Crop. Sci. 5, 709- 
13. Limmer M, Burken J (2016): Phytovolatilization of organic contaminants. Environ. Sci. Technol. 50, $6632-43$

14. Liu H, Zhang S, Zhang X, Chen C (2015a): Growth inhibition and effect on photosystem by three imidazolium chloride ionic liquids in rice seedlings. J. Hazard. Mater. 286, 440-448

15. Liu H, Wu J, Zhang X, Xia Y, Li Y, Du S (2017): Enantioselective oxidative stress caused by chiral ionic liquids forms of 1-alkyl-3-methyl imidazolium tartrate on Scenedesmus obliquus. Sci.Total Environ. $595,819-827$

16. Liu T, Zhu L, Wang J, Wang J, Xie H (2015b): The genotoxic and cytotoxic effects of 1-butyl-3methylimidazolium chloride in soil on Vicia faba seedlings. J Hazard Mater 285, 27-36

17. Liu Y, Zhu LS, Wang JH, Wang J, Zhang J, Sun X, Zhang C (2015c): Biochemical toxicity and DNA damage of imidazolium-based ionic liquid with different anions in soil on Vicia faba seedlings. Scientific Reports 5, 18444

18. Miller EL, Nason SL, Karthikeyan KG, Pedersen JA (2016): Root Uptake of pharmaceuticals and personal care product ingredients. Environ. Sci. Technol. 50, 525-541

19. Nason SL, Miller EL, Karthikeyan KG, Pedersen JA (2019): Effects of binary mixtures and transpiration on accumulation of pharmaceuticals by Spinach. Environ. Sci. Technol. 53, 4850-4859

20. Oskarsson A, Wright MC (2019): lonic liquids: New emerging pollutants, similarities with perfluorinated alkyl substances (PFASs). Environ. Sci. Technol. 53, 10539-10541

21. Polesel F, Plósz BG, Trapp S (2015): From consumption to harvest: Environmental fate prediction of excreted ionizable trace organic chemicals. Water. Res. 84, 85-98

22. Ranke J, Müller A, Bottin-Weber U, Stock F, Stolte S, Arning J, Störmann R, Jastorff B (2007): Lipophilicity parameters for ionic liquid cations and their correlation to in vitro cytotoxicity. Ecotoxic. Environ. Safe. 67, 430-438

23. Riaz L, Mahmood T, Coyne MS, Khalid A, Rashid A, Hayat MT, Gulzar A, Amjad M (2017): Physiological and antioxidant response of wheat (Triticum aestivum) seedlings to fluoroquinolone antibiotics. Chemosphere 177, 250-257

24. Rico CM, Morales MI, McCreary R, Castillo-Michel H, Barrios AC, Hong J, Tafoya A, Lee W-Y, VarelaRamirez A, Peralta-Videa JR, Gardea-Torresdey JL (2013): Cerium oxide nanoparticles modify the antioxidative stress enzyme activities and macromolecule composition in rice seedlings. Environ. Sci. Technol. 47, 14110-14118

25. Sicbaldi F, Sacchi GA, Trevisan M, Del Re AAM (1997): Root uptake and xylem translocation of pesticides from different chemical classes. Pestic. Sci. 50, 111-119

26. Spasiano D, Siciliano A, Race M, Marotta R, Guida M, Andreozzi R, Pirozzi F (2016): Biodegradation, ecotoxicity and $\mathrm{UV}_{254} / \mathrm{H}_{2} \mathrm{O}_{2}$ treatment of imidazole, 1-methyl-imidazole and $\mathrm{N}, \mathrm{N}$-alkyl-imidazolium chlorides in water. Water. Res. 106, 450-460 
27. Stolte S, Matzke M, Arning J, Boschen A, Pitner W-R, Welz-Biermann U, Jastorff B, Ranke J (2007): Effects of different head groups and functionalised side chains on the aquatic toxicity of ionic liquids. Green. Chem. 9, 1170-1179

28. Thuy Pham TP, Cho C-W, Yun Y-S (2010): Environmental fate and toxicity of ionic liquids: A review. Water. Res. 44, 352-372

29. Trapp S (2000): Modelling uptake into roots and subsequent translocation of neutral and ionisable organic compounds. Pest. Manag. Sci. 56, 767-778

30. Trapp S (2004): Plant uptake and transport models for neutral and ionic chemicals. Environ Sci \& Pollut Res 11, 33-39

31. Xu Y, Wang J, Zhu L, Du Z, Wang J, Wei K (2018): Physiological and biochemical responses of wheat (Triticum aestivum L.) seedlings to three imidazolium-based ionic liquids in soil. Chemosphere 191, 81-88

32. Xu Y, Wang J, Du Z, Li B, Juhasz A, Tan M, Zhu L, Wang J (2020): Toxicity evaluation of three imidazolium-based ionic liquids $\left(\left[\mathrm{C}_{6} \mathrm{mim}\right] \mathrm{R}\right)$ on Vicia faba seedlings using an integrated biomarker response (IBR) index. Chemosphere 240, 124919

33. Yuan L, Richardson CJ, Ho M, Willis CW, Colman BP, Wiesner MR (2018): Stress responses of aquatic plants to silver nanoparticles. Environ. Sci. Technol. 52, 2558-2565

34. Zhang H, He X, Zhang Z, Zhang P, Li Y, Ma Y, Kuang Y, Zhao Y, Chai Z (2011): Nano- $\mathrm{CeO}_{2}$ exhibits adverse effects at environmental relevant concentrations. Environ. Sci. Technol. 45, 3725-3730

\section{Figures}

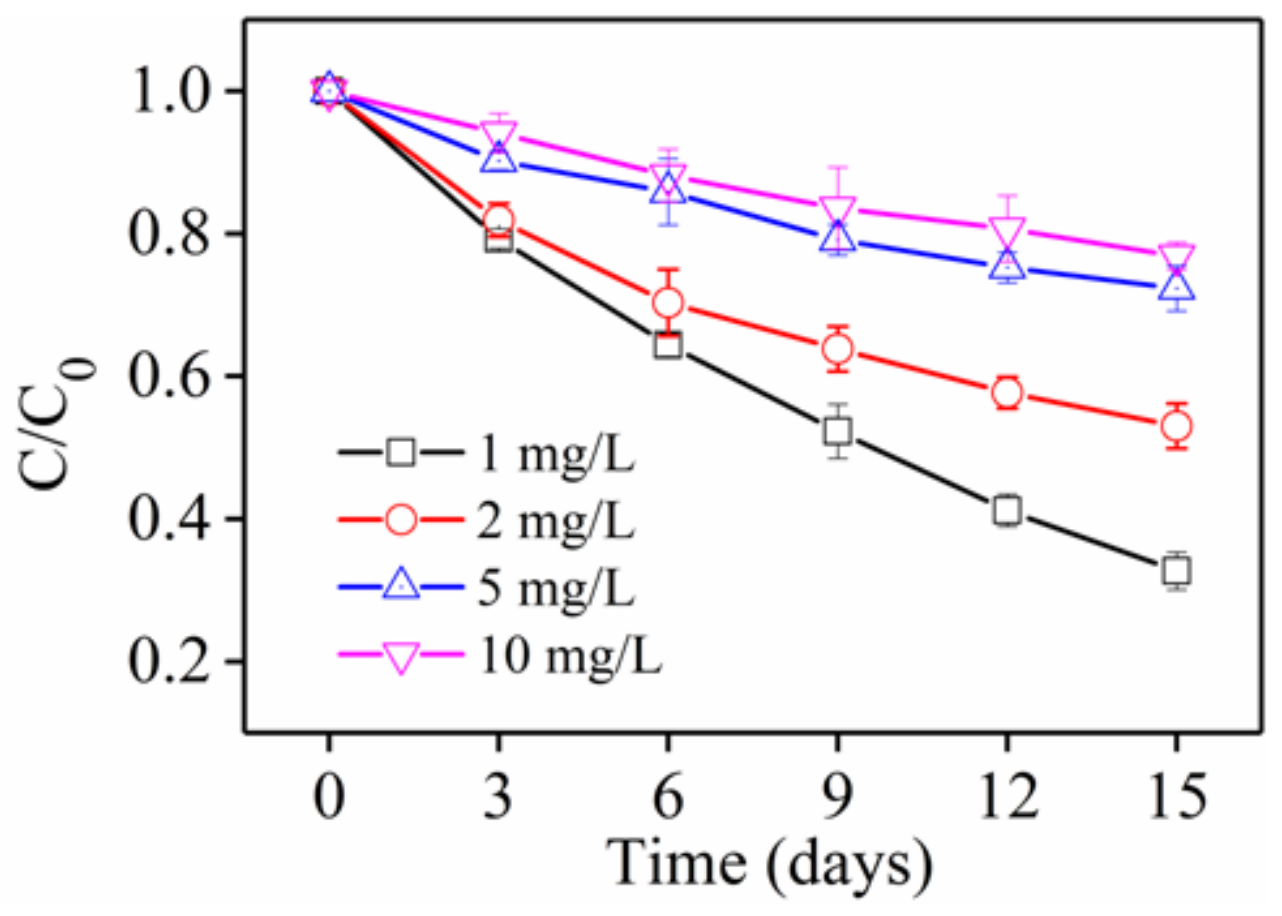

Figure 1 
Removal of [C14mim] Br from ryegrass at different concentrations

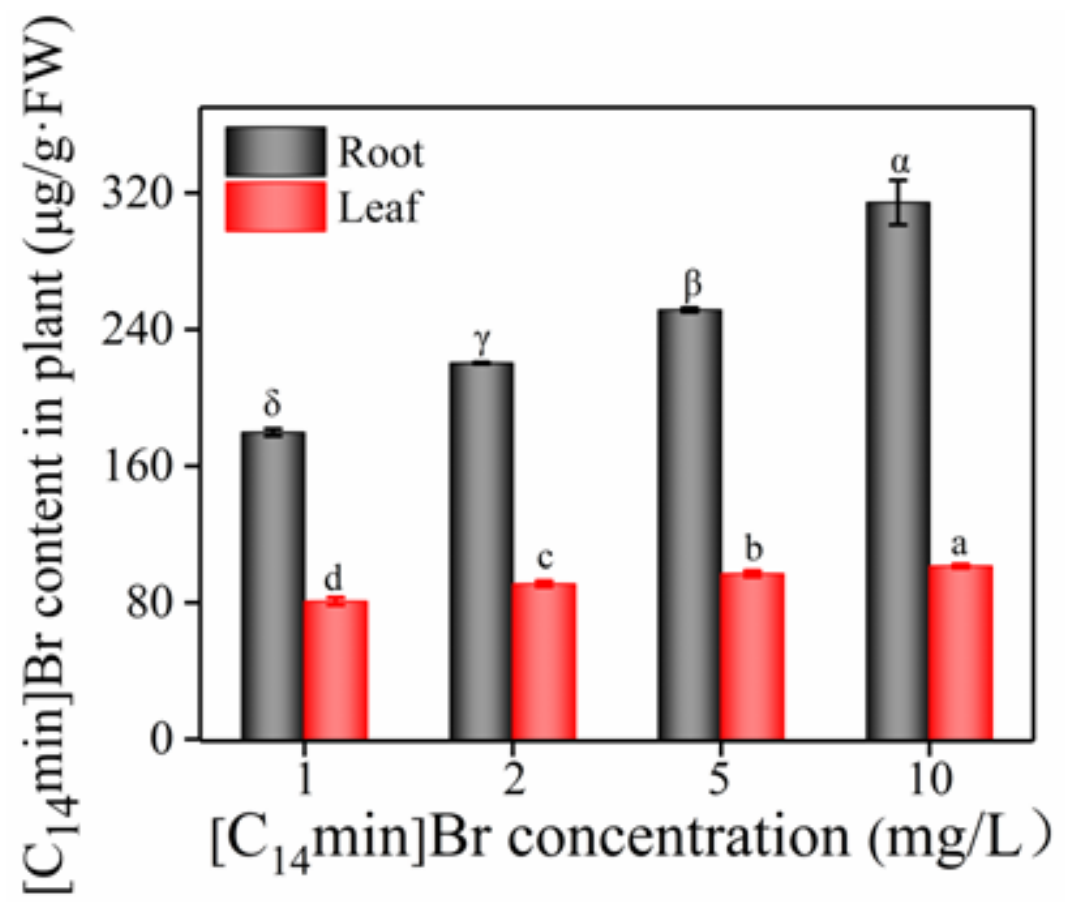

Figure 2

Accumulation of [C14mim] $\mathrm{Br}$ in ryegrass roots and leaves 

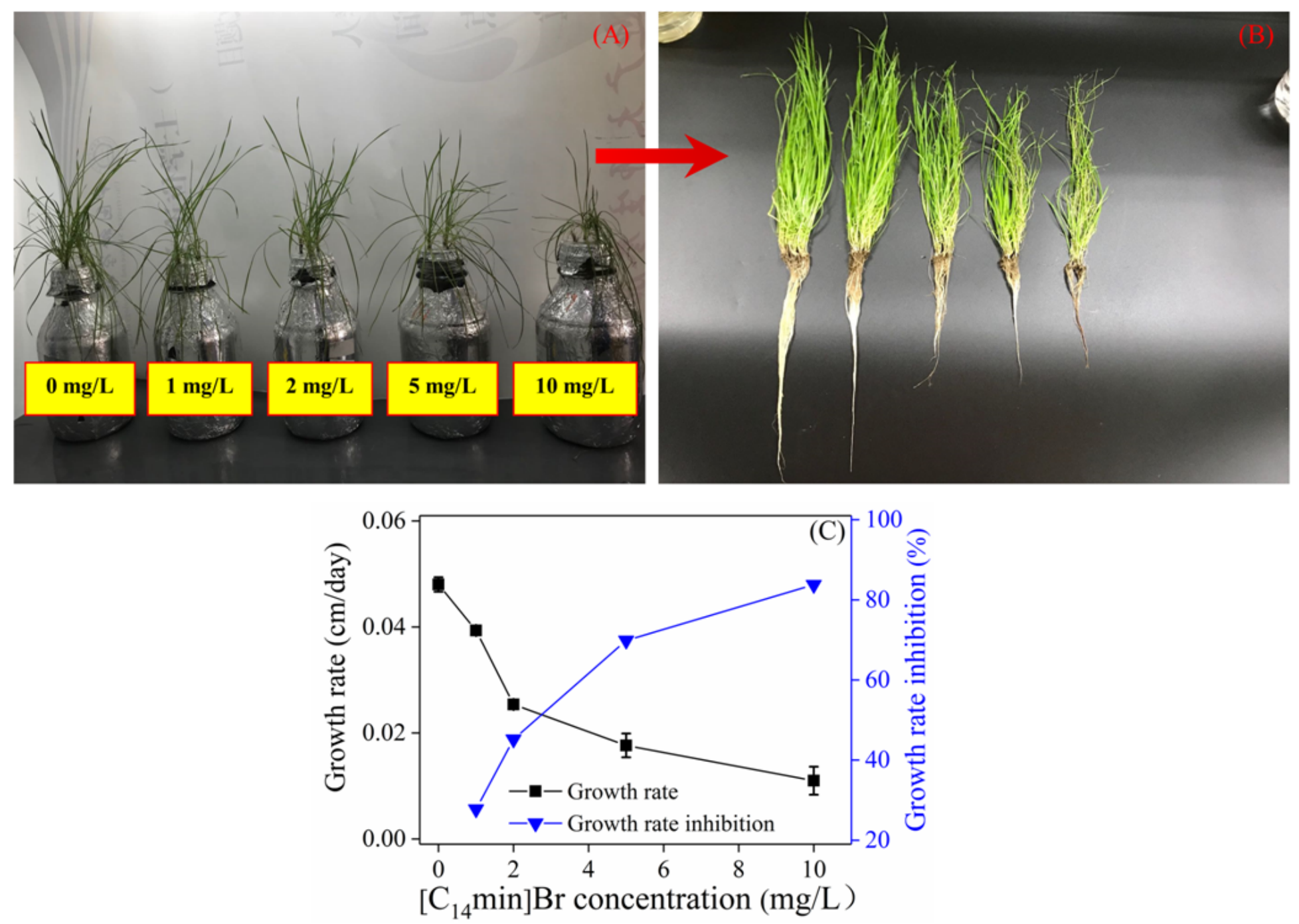

Figure 3

Images of ryegrass growth after a 15-day exposure to [C14mim] $\mathrm{Br}$ and growth inhibition rate of ryegrass
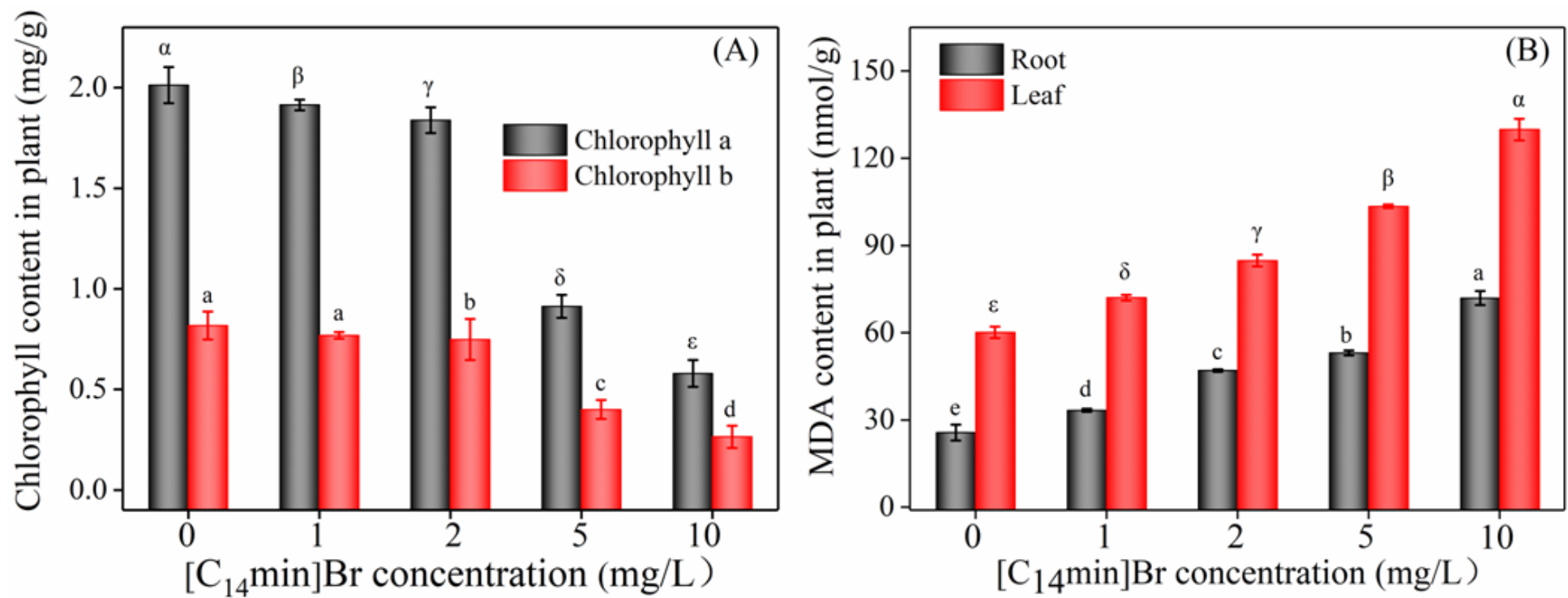
Figure 4

Effect of ionic [C14mim]Br different concentration on chlorophyll (A) andMDA content in ryegrass (B).

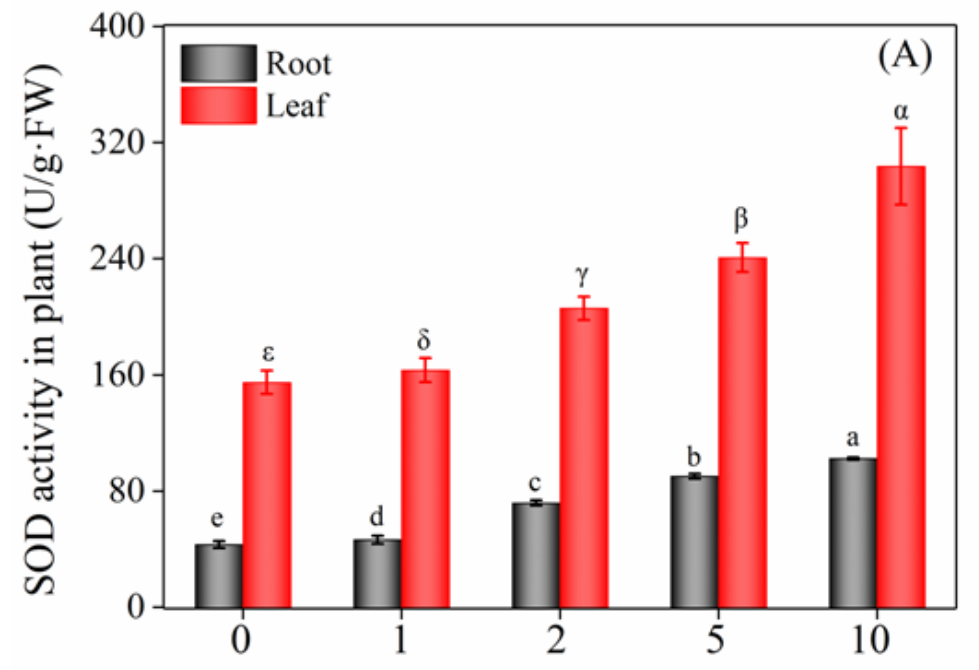

$\left[\mathrm{C}_{14} \min \right] \mathrm{Br}$ concentration $(\mathrm{mg} / \mathrm{L})$

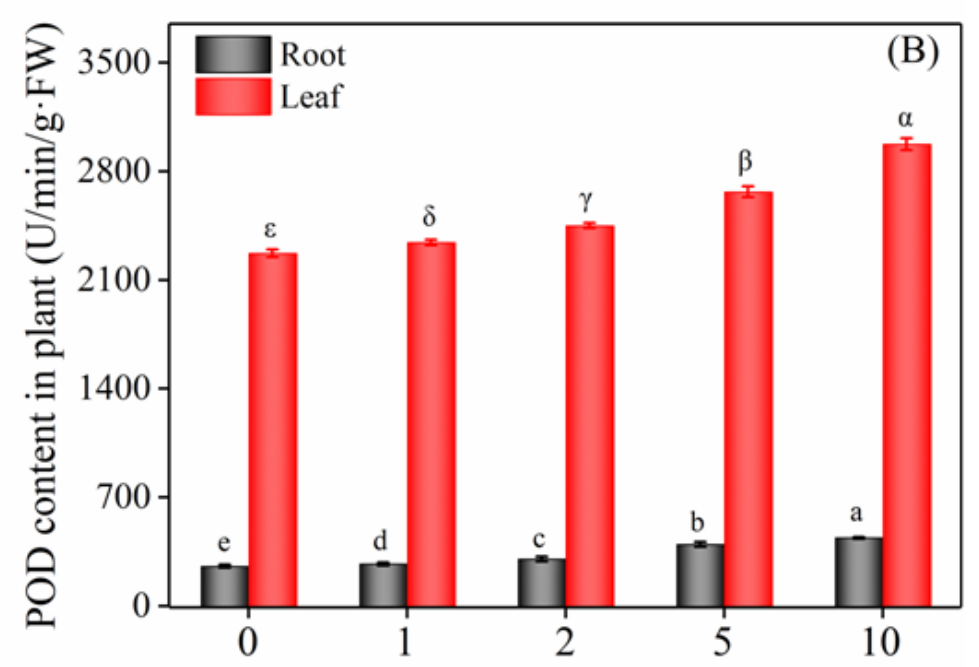

$\left[\mathrm{C}_{14} \mathrm{~min}\right] \mathrm{Br}$ concentration $(\mathrm{mg} / \mathrm{L})$

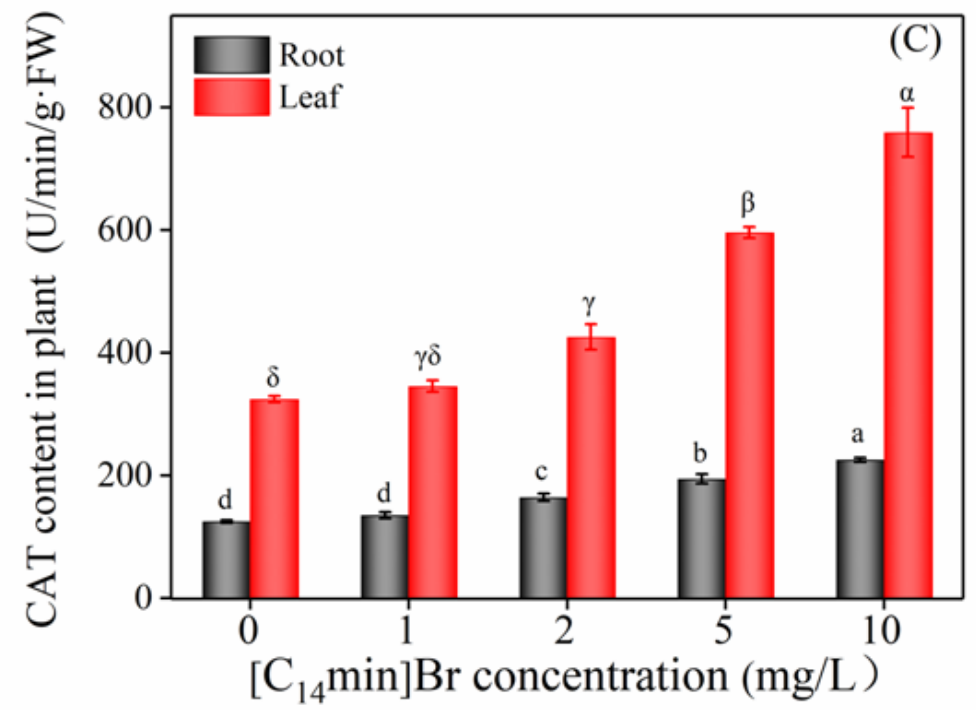

Figure 5

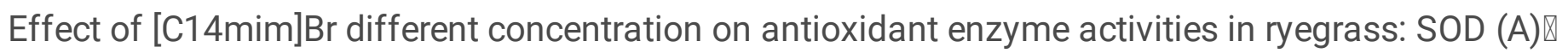
POD (B) $₫ C A T(C)$.

\section{Supplementary Files}

This is a list of supplementary files associated with this preprint. Click to download.

- GraphicAbstract.png 